\title{
Game Edukasi Pembelajaran IPA Berbasis Visual Novel Studi Kasus: SDN Cibalongsari IV Karawang
}

\author{
Hafiz Abdul Fatah ${ }^{1}$, Asep Jamaludin ${ }^{2}$, Nono Heryana ${ }^{3}$ \\ 1,2,3 Teknik Informatika, Fakultas Ilmu Komputer \\ Universitas Singaperbangsa Karawang \\ Jl. HS. Ronggo Waluyo Telukjambe Timur Karawang \\ e-mail: ${ }^{1}$ hafiz.16099@ student.unsika.ac.id, ${ }^{2}$ asep.jamaludin@ @staff.unsika.ac.id, \\ ${ }^{3}$ nono@cs.unsika.ac.id
}

Diterima: 20 Agustus 2020; Direvisi: 11 September 2020; Disetujui: 1 Oktober 2020

\begin{abstract}
Abstrak
Saat ini media yang digunakan dalam pembelajaran ekosistem makhluk hidup kelas 5 pada SDN Cibalongsari IV Karawang hanya berupa buku, papan tulis dan beberapa alat peraga sehingga siswa menjadi kurang tertarik serta cepat merasa bosan, Game edukasi visual novel merupakan alternatif lain dalam meningkatkan minat dan ketertaikan siswa terhadap materi tersebut. Metodelogi yang digunakan dalam penelitian ini yaitu Mulitimedia Development Life Cycle. Game ini memuat materi ekosistem makhluk hidup dengan 3 sub bagian yaitu pengertian, jenis golongan hewan, dan jenis ekosistem. Uji coba game edukasi ini menggunakan uji-t berpasangan dan UAT, yang menghasilkan persentase tingkat signifikan $t$ hitung $=3,7549>$ nilai $t$ tabel $=$ $(\propto=0.01, d f=27)=2.47266$ sehingga Ho berada didaerah penolakan dan H1 diterima, serta dalam uji rata-rata menggunakan persentase nilai pre test dan post test menggunakan game edukasi sebagai media pembelajaran mengalami peningkatan dari 58,21\% menjadi sebesar $72,5 \%$ dengan selisih 14,29\%. dan dalam pengujian menggunakan UAT berdasarkan penilaian siswa mendapat hasil positif dalam setiap pertanyaan yang menyatakan game ini memiliki fitur yang cukup untuk menarik siswa paham akan materi dan juga game edukasi ini dapat diterima sebagai media alternatif pada proses pembelajaran.
\end{abstract}

Kata kunci: Game Edukasi, MDLC, Visual novel, Unity, Ekosistem Makhluk Hidup

\begin{abstract}
Currently, the media used in learning the 5th grade living ecosystem at SDN Cibalongsari IV Karawang is only in the form of books, whiteboards and some props so that students become less interested and quickly feel bored, visual novel educational games are another alternative in increasing student interest and awareness. against the material. The methodology used in this study is the Multimedia Development Life Cycle. This game contains material on living ecosystems with 3 sub-sections, namely understanding, types of animal groups, and types of ecosystems. This educational game trial uses paired t-test and UAT, which results in a significant level of percentage $t$ count $=>t$ table value so that $H o$ is in the rejection area and $H 1$ is accepted, and in the average test uses the percentage of the pre-test and post-test values using the game. education as a learning medium has increased from being equal to a difference and in testing using UAT based on student assessments it gets positive results in each question which states that this game has sufficient features to attract students to understand the material and also this educational game can be accepted as an alternative media in learning process.
\end{abstract}

Keywords: Educational Games, MDLC, Visual novels, Unity, Ecosystems of Living Things 


\section{PENDAHULUAN}

IPA adalah cabang ilmu pengetahuan yang meneliti tentang makhluk hidup yang ada di alam semesta baik tumbuhan, hewan, maupun manusia. Baik yang saling berinteraksi, passive, dan aktif. Pada saat ini sistem belajar yang di terapkan pada sekolah dasar menggunakan kurikulum 2013 revisi yang berfokus pada generasi muda yang mampu berpikir, berinovasi, kreatif, efektif dan berkomunikasi jernih dan luas.

Pada hasil survei yang di dapat pada gambar 1 dengan melihat data nilai ulangan siswa kelas 5 SDN Cibalongsari IV Karawang dapat di simpulkan pada mata pelajaran IPA dan Matematika merupakan nilai dengan rata-rata terendah dengan jumlah nilai 74.

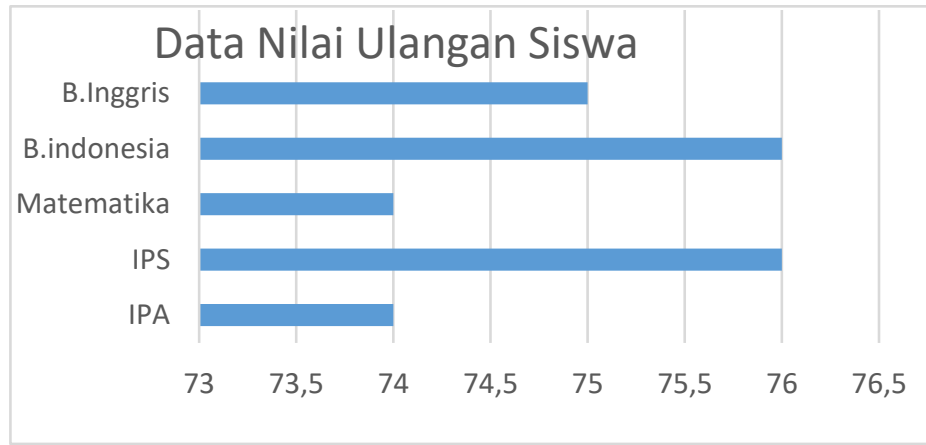

Gambar 1. Survei data nilai siswa

Penelitian ini peneliti fokus pada pelajaran Ilmu Pengetahuan Alam, dikarenakan pada pelajaran matematika siswa sudah menggunakan metode Fun math, yang artinya media pembelajaran ini sudah signifikan dengan metode yang lebih menarik. Pada pelajaran Bahasa Inggris pembelajaran sudah menerapkan media gambar dan bermain dialog yang membuat pelajaran lebih menarik. Sedangkan dalam pelajaran IPA menggunakan metode konvensional dan terkadang menggunakan alat peraga untuk membantu menyampaikan materi, dampak dari penerapan media pembelajaran ini sudah cukup baik, tapi ada beberapa materi yang sulit untuk dipahami yang membutuhkan penalaran dan hafalan, yang membuat siswa menjadi bingung dan sulit memahami materi.

Hal ini juga disetujui oleh pengajar kelas 5 SDN Cibalongsari IV Karawang, ibu Tati Haryati S, S.Pd, ketika di wawancara, bahwa memang pada pelajaran IPA siswa sulit untuk memahami materi serta terlambatnya buku bacaan yang dikirim dari pusat, yang membuat siswa harus belajar dengan media yang sangat minim, sehingga kurangnya ketertarikan siswa pada pelajarannya tersebut, terbukti pada nilai ulangan yang rendah dengan rata-rata 75 dan masih banyak yang mendapatkan nilai kurang dari 70 .

Ekosistem makhluk hidup sendiri merupakan salah satu dari 5 lingkup materi penting dalam kisi-kisi ujian nasional, dalam materi ekosistem makhluk hidup terdapat 9 poin pemahaman materi, yang berarti jumlah soal yang ada pada ujian nasional tentang ekosistem makhluk hidup minimal 9 soal dan bisa lebih dari itu, dengan kurikulum 2013 revisi 2017 ada peningkatan materi dari jenis penggolongan berdasarkan tengkorak dan jenis gigi pada hewan.

Permainan edukasi sangat menarik buat dikembangkan. Terdapat sebagian kelebihan dari permainan edukasi dibanding dengan metode edukasi konvensional. Salah satu kelebihan utama permainan edukasi merupakan pada visualisasi dari kasus nyata. Massachussets Insitute of Technology( MIT) sukses meyakinkan kalau permainan sangat bermanfaat buat tingkatkan logika serta pemahaman pemain terhadap sesuatu permasalahan lewat proyek permainan yang dinamai Scratch [1] . 
Visual novel bisa jadi media pendidikan alternatif, sebab visual novel pada biasanya merupakan potensi baru yang bukan cuma berbentuk konten visual, tetapi juga mempunyai konten interaktif antara pembaca( pemain) serta cerita [2]. Interaktivitas ini menciptakan kebebasan yang membolehkan terdapatnya kepribadian serta latar yang unik. Dengan keunggulan tersebut serta proses integrasi pendidikan pada visual novel, sangat bisa jadi untuk visual novel buat memperoleh atensi belajar siswa.

Berdasarkan permasalahan yang telah dibahas, maka peneliti dapat memberi sebuah alternatif pemecahan masalah yaitu dengan pengembangan media pembelajaran berbasis game edukasi visual novel yang merupakan sebuah game interaktif yang berfokus pada alur cerita, pengetahuan dan dikemas dengan gambar seperti kartun. Sehingga dapat meningkatkan daya kembang anak serta meningkatkan keinginan anak dalam hal belajar.

\section{METODE PENELITIAN}

Metode yang digunakan dalam riset ini yakni Multimedia Development Life Cycle (MDLC), dan dalam tahap pengujian aplikasi ini menggunakan teknik penelitian tindakan kelas (PTK) sebagai pengujian Beta Teting pada kelas 5, SDN Cibalongsari IV Karawang.

\subsection{Multimedia Development Life Cycle}

Multimedia Development Life Cycle adalah metode dari model pengembangan luther [3], ada 6 tahapan dalam MDLC pada gambar 2 yaitu [4] :

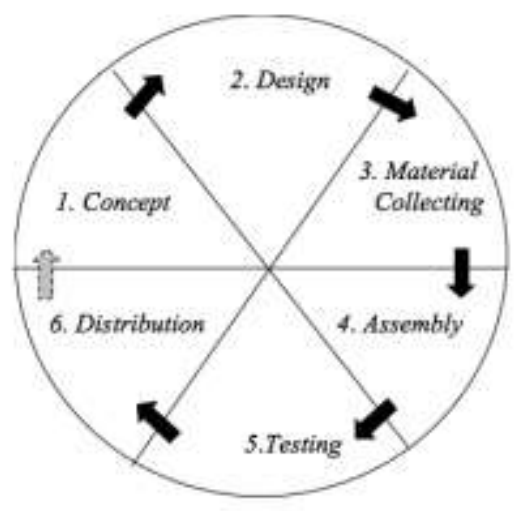

Gambar 2. Tahapan model pengembangan multimedia Luther-Sutopo

1. Concept

Pada tahapan concept tahap menentukan tujuan dan untuk siapa aplikasi ini di buat, manfaat aplikasi media pembelajaran, pengguna media pembelajaran, serta menjelaskan konsep dasar aplikasi yang akan di bangun.

2. Design

Design merupakan tahapan membuat spesifikasi berbagai materi dari arsitektur program, tampilan, serta kebutuhan bahan/ tekstur yang lain.Material Collecting.

\section{Material Collecting}

Tahap ini pengumpulan bahan yang cocok dengan kebutuhan yang hendak dikerjakan, bahan- bahan tersebut berbentuk foto clip art, audio, gambar, animasi, video, serta yang lain.

4. Assembly 
Tahap ini adalah tahap pembuatan semua objek atau bahan multimedia lainnya, pembuatan aplikasi ini didasarkan pada tahap design dengan mengikuti storyboard atau bagan alir, dan alur yang di buat.

5. Testing

Tahap ini dilakukan dengan menjalankan aplikasi dan melihat apakah ada kesalahan atau tidak, tahap ini di sebut juga sebagai tahap pengujian Alpha (Alpha Test) yang pengujiannya dilakukan oleh developer atau lingkungan penguji. Setelah melakukan pengujian Alpha, selanjutnya pengujian Beta yang melibatkan penggunaan akhir.

6. Distribution

Tahap ini di mana aplikasi di simpan, aplikasi media penyimpanan tidak cukup maka dilakukan proses kompresi, tahap ini juga di sebut tahap evaluasi agar produk bisa lebih baik lagi.

\subsection{Penelitian Tindakan Kelas}

Istilah penelitian tindakan berasal dari Bahasa inggris yaitu "action research", metode ini adalah metode penelitian yang di kembangkan pada tahun 1940 an sebagai metode penelitian di tempat kerja di mana peneliti melakukan pekerjaan pokok sehari-hari [5]. Penelitian tindakan kelas berarti meneliti perkembangan perilaku siswa di kelas dengan mengamati kegiatan seharihari siswa.

\section{HASIL DAN PEMBAHASAN}

Hasil akhir yang didapat dari penelitian ini adalah media pembelajaran berbentuk game interaktif berbentuk Compact Disk (CD). Game ini meliputi beberapa pilihan menu, diantaranya mulai, kompetensi dasar, dan about. tahap pertama (concept) sampai dengan tahap terakhir (distribution), akan dijelaskan sebagai berikut:

\subsection{Concept}

Pada tahap ini, aplikasi di rancang dengan sangat menarik, sederhana, dan dapat di mengerti oleh anak-anak. Dalam fungsinya terdapat beberapa pilihan menu dan setiap pilihan menu mengarahkan ke materi yang di pilih, sehingga membuat pelajaran sangat interaktif.

Berdasarkan analisis permasalahannya, maka Game edukasi yang akan dikembangkan adalah bergenre Visual novel, serta dilengkapi dengan kuis. Genre Visual novel ini diketahui cocok digunakan karena interaksinya dapat membuat pembelajaran di dalam Game menjadi menarik. Serta dengan adanya kuis membuat siswa dapat menyerap materi yang ada pada Game dapat lebih baik. Konsep Game dan Materi Pembelajarannya dapat di lihat di tabel 1 berikut ini:

Tabel 1. Konsep game

\begin{tabular}{ll}
\hline Judul & Ekosistem Education Game \\
\hline Jenis Game & Jenis Game yang akan dibuat merupakan jenis Game edukasi dengan genre Visual \\
(genre) & novel. Namun di dalam Game juga akan ditambahkan Kuis untuk menguji kepahaman \\
materi. & Menu di dalam Game ini terdiri dari: \\
& a. Mulai \\
& b. Kompetensi Dasar \\
& c. About \\
& d. Exit \\
\hline Jumlah scene & Jumlah scene yang digunakan untuk materi pembelajaran adalah 3, yaitu: \\
Menu Mulai & a. Pengertian Ekosistem \\
& b. Golongan Hewan Berdasarkan Jenis Makanan \\
& c. Jenis Ekosistem
\end{tabular}




\begin{tabular}{ll}
\hline Judul & Ekosistem Education Game \\
\hline Jumlah scene & $\begin{array}{l}\text { Dalam Materi Kuis terdapat 10 soal dengan 4 pilihan jawaban soal terseut memuat } \\
\text { materi ekosistem mulai dari pengeritan, golongan hewan berdasarkan jenis makanan, } \\
\text { dan jenis ekosistem. }\end{array}$ \\
Sistem skor & $\begin{array}{l}\text { Sistem skor pada Permainan edukasi ini adalah apabila tiap jawaban untuk kuis benar } \\
\text { akan mendapatkan nilai skor 10 serta apabila salah tidak memperoleh skor. }\end{array}$ \\
Target & $\begin{array}{l}\text { Permainan yang dihasilkan ialah Permainan 2D berbasis desktop yang bisa berjalan di } \\
\text { Platform Windows. Format file yang digunakan adalah. exe sehingga tidak dibutuhkan } \\
\text { proses instalasi yang rumit }\end{array}$ \\
\hline
\end{tabular}

\subsection{Design}

Tahap desain adalah tahap yang digunakan untuk mendesain perangkat lunak yang akan dikembangkan. Tahap desain meliputi struktur navigasi pada gambar 3, storyboard pada gambar 4, dan desain interface. Desain perangkat lunak mengacu dari hasil analisis kebutuhan. Berikut rancangan struktur navigasi yang sudah dibuat:

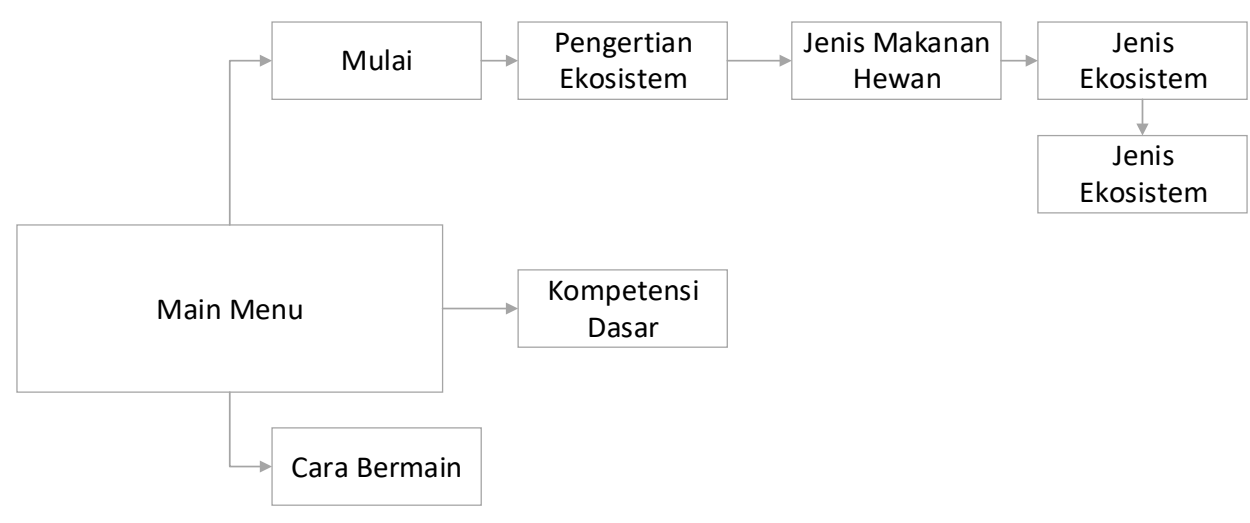

Gambar 3. Struktur navigasi game

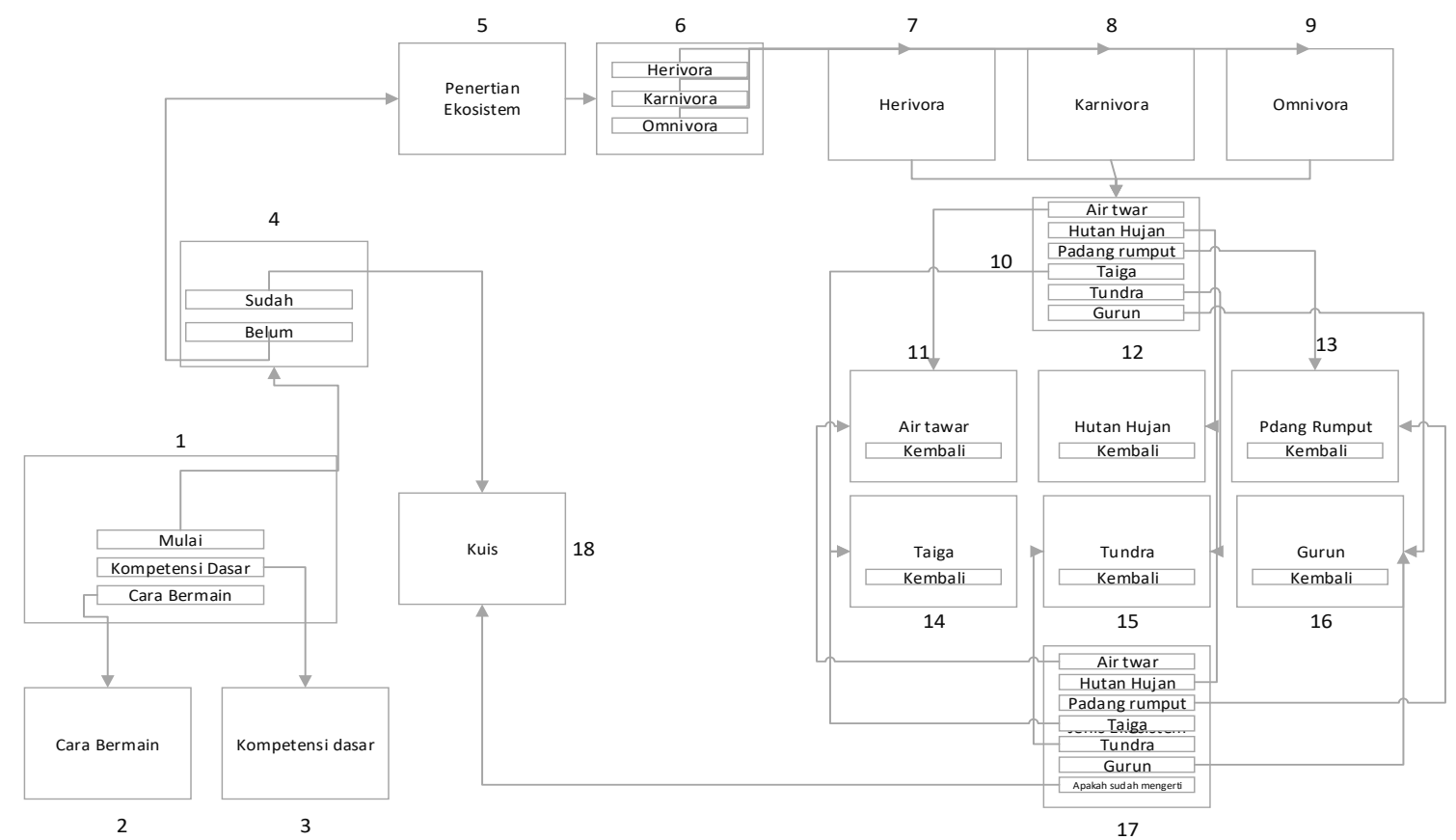

Gambar 4. Storyboard aplikasi 


\subsection{Material Collecting}

Pada tahap ini peneliti mengumpulkan semua bahan-bahan atau material untuk kebutuhan database multimedia aplikasi. Baik yang telah di dapatkan dari berbagai sumber di internet, buku, maupun yang buatan peneliti [6].

\subsection{Assembly}

Pada tahap ini peneliti mulai melakukan pembuatan game edukasi sebagai media pembelajaran dan mengolah semua bahan yang sudah dikumpulkan pada tahap sebelumnya, lalu kemudian merangkainya menjadi game edukasi yang membahas tentang Ekosistem Makhluk Hidup dan diberi nama game "Ekosistem Education Game".

\section{A. Splashscreen}

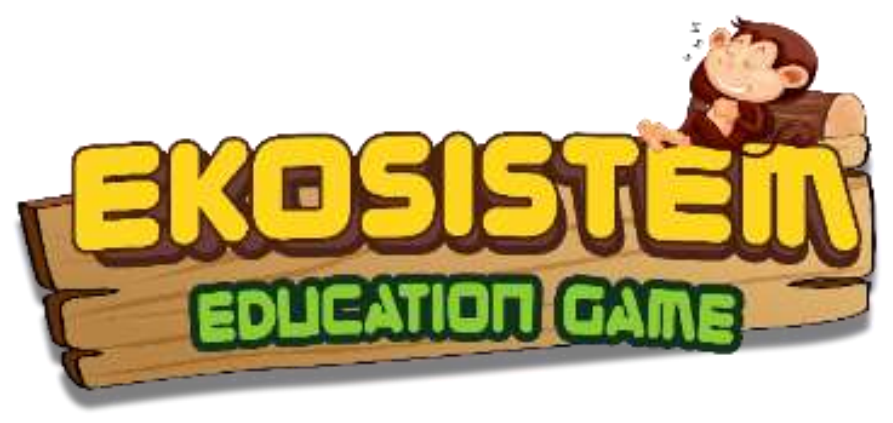

Gambar 5. Desain splashscreen

Splahscreen pada gambar 5 adalah tampilan yang pertama kali muncul sebelum permainan dimulai. Ekosistem Education Game merupakan nama dari game ini.

B. Menu Utama

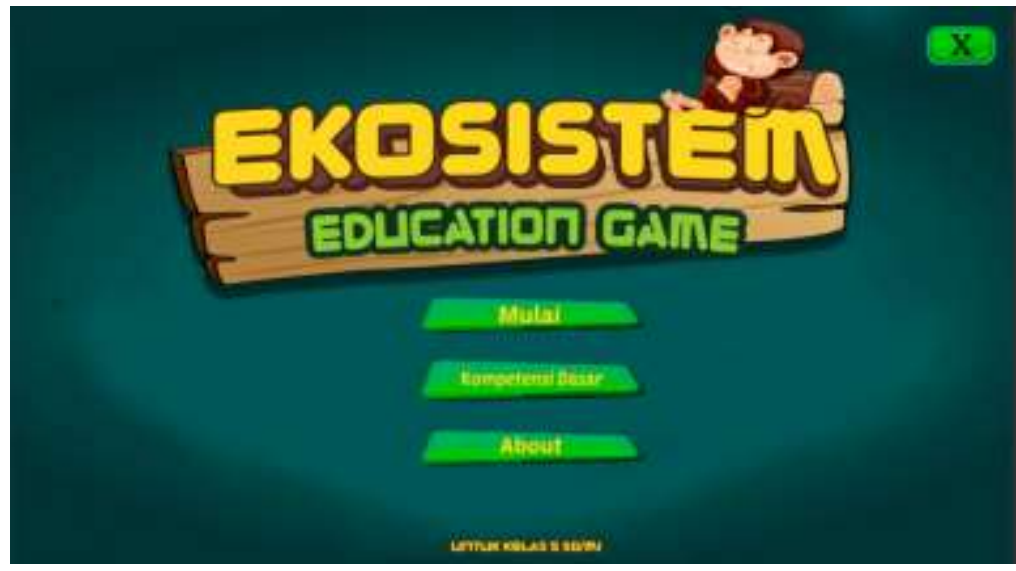

Gambar 6. Desain menu utama di dalam game

Menu utama muncul setelah tampilan splashscreen selesai. Tampilan Menu Utama pada gambar 6 terdiri dari button untuk memilih Mulai, About, Kompetensi Dasar, dan juga Exit.

C. Menu Mulai 


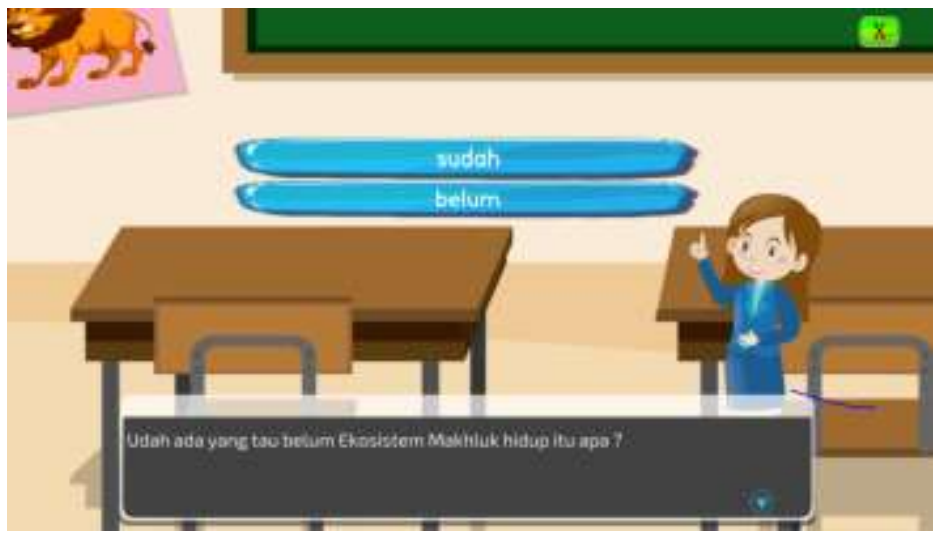

Gambar 7. Gameplay

Ketika pemain memilih dan klik tombol Mulai, maka pemain akan di arahkan ke menu Gameplay di mana ada beberapa tahapan tiap tahapan tersbeut di sesuaikan dengan silabus materi ekosistem seperti pada gambar 7.

\section{Menu KD (Kompetensi Dasar)}

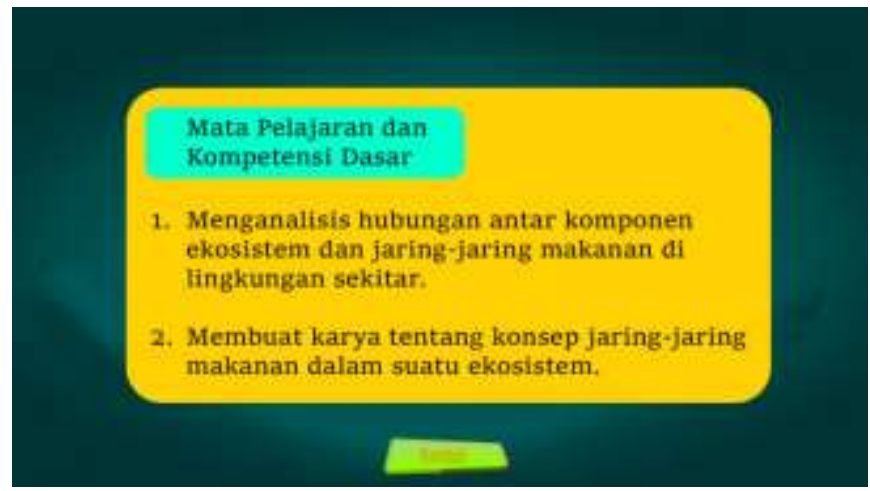

Gambar 8. Desain menu kompetensi dasar

Menu KD pada gambar 8 digunakan untuk menjelaskan tentang kompetensi dasar dan juga Mata pelajaran yang ingin dipaparkan melalui game edukasi ini.

\section{E. Menu Kuis}

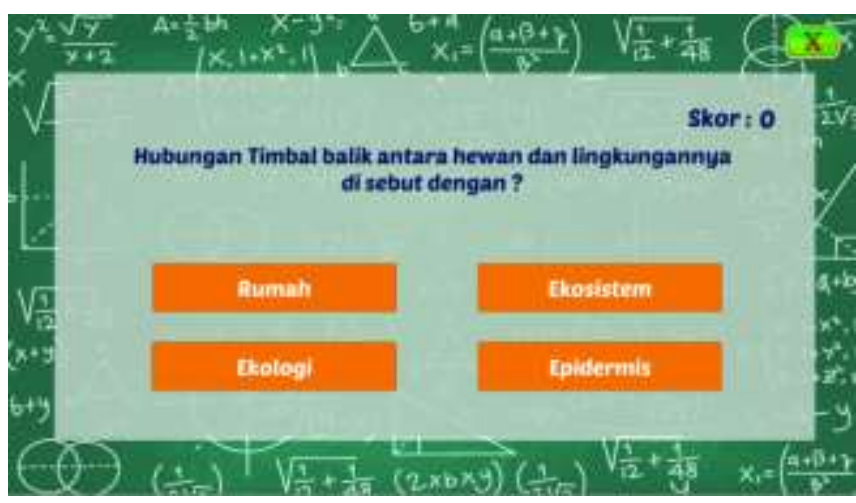

Gambar 9. Desain kuis 
Setelah materi selesai dan pengguna klik button Kuis, akan muncul scene kuis yang terdiri dari 10 soal yang berurutan secara stastis dari materi yang ada seperti pada gambar 9 . Untuk jawaban yang benar akan mendapatkan skor 10 dan untuk jawaban yang salah maka akan mendapatkan skor 0. Berikut salah satu tampilan kuis untuk materi Ekosistem Makhluk Hidup.

F. About

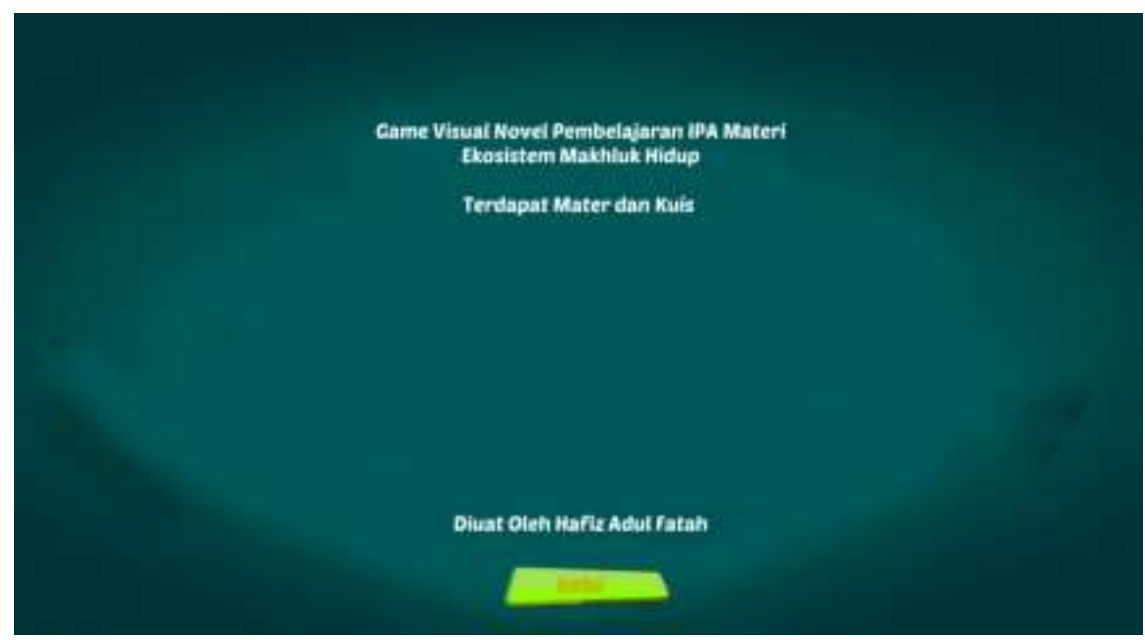

Gambar 10. Desain about panel scene

Pada gambar 10 menampilkan tujuan game edukasi, jenis materi, jenis game dan pemuat aplikasi.

\section{G. Proses Pembuatan}

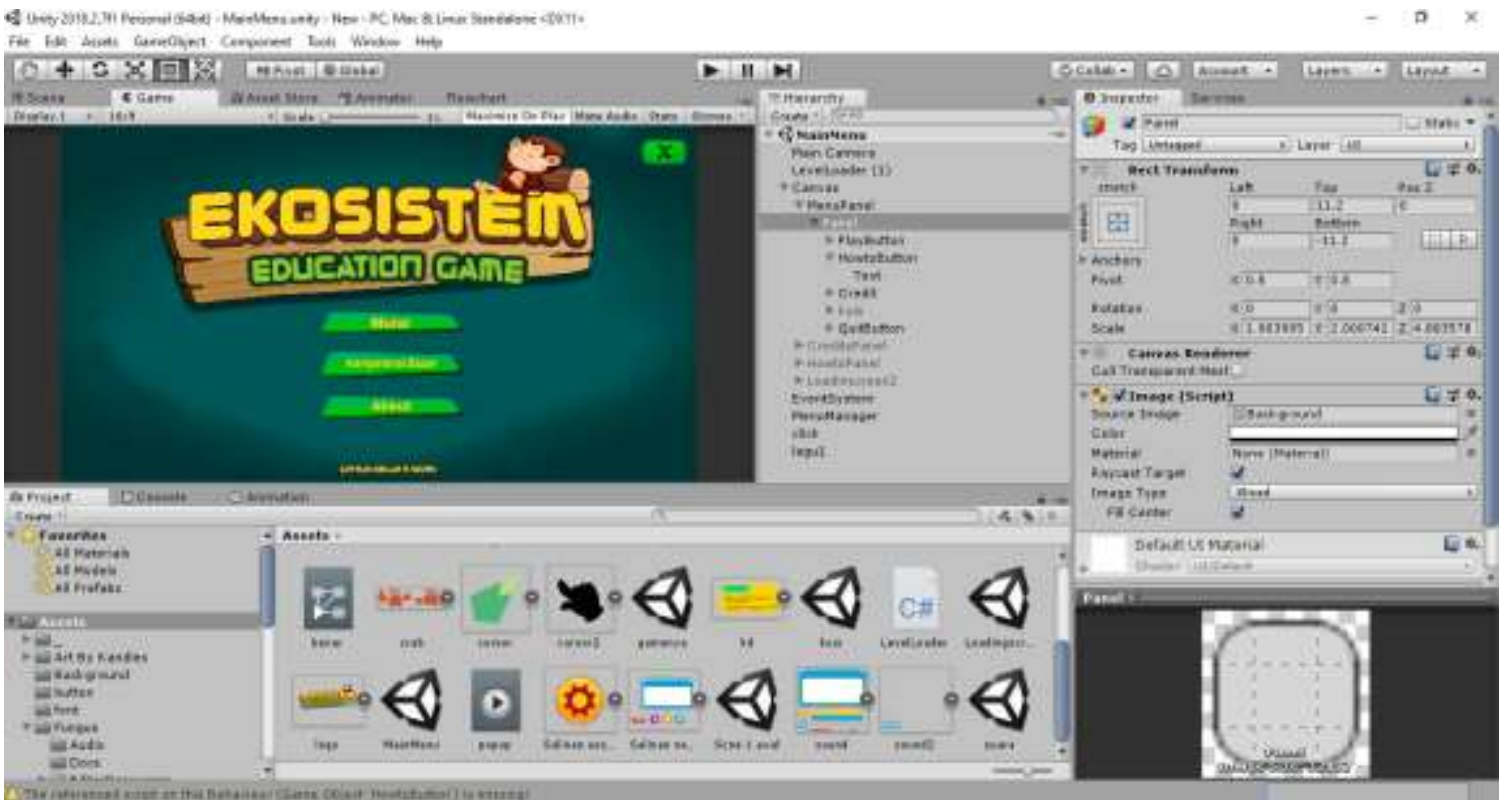

Gambar 11. Pembuatan scene 
Pada pembuatan scene Main Menu seperti pada gambar 10, ada beberapa komponen game objek yang terlihat pada gambar 12 ini:

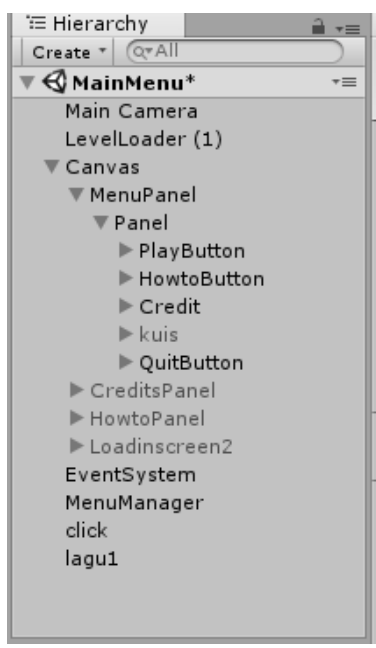

Gambar 12. Game objek komponen penyusun scene

Tiap komponen memiliki properties, di mana melalui properties tersebut bisa diberikan action ketika tombol di klik, bisa diberikan fungsi perpindahan scene, dan atribut lainnya yang tampak pada gambar 13 .

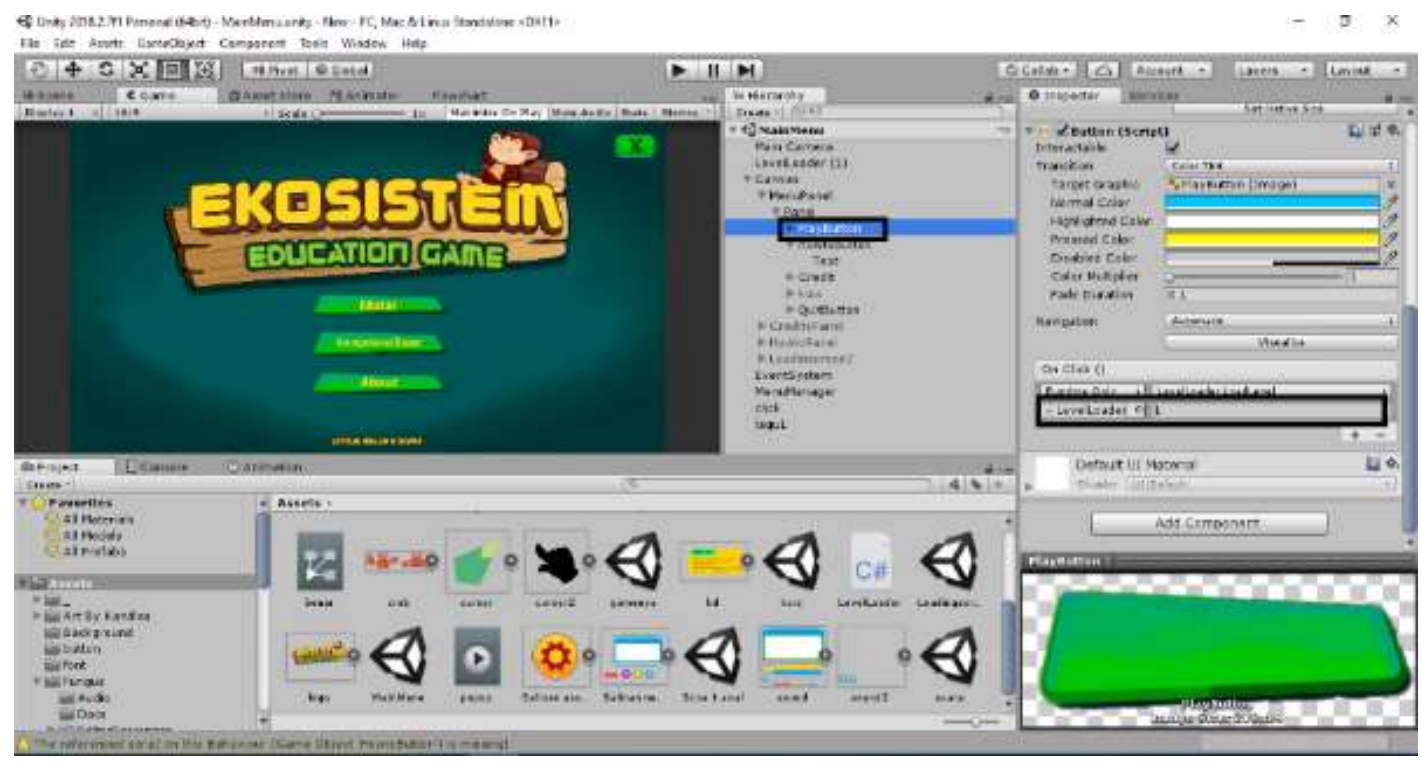

Gambar 13. Properties game objek pada scene

\subsection{Testing}

Pada tahap ini di lakukan 2 pengujian yang pertama pengujian Alpha yang bertujuan untuk menguji fungsional dan non fungsional dari aplikasi, kemudian pengujian beta untuk menguji kualitas perangkat lunak oleh pengguna (user).

\section{A. Pengujian Alpha}

Pengujian Alpha dilakukan untuk mengetahui kesalahan pada fungsional perangkat lunak, apakah perangkat lunak telah berjalan sesuai dengan yang di harapkan [7].

a. Pengujian Fungsional 
Pengujian ini dilakukan oleh penguji dengan menguji semua elemen beserta fungsinya yang terdapat di dalam Game Edukasi ini. Pengujian dilakukan agar mengetahui apakah hasil yang diinginkan sesuai yang diharapkan atau tidak, selain itu pengujian ini bertujuan menunjukan kemungkinan kesalahan yang terjadi dalam setiap proses.

1. Pengujian fungsi menu utama

Pada tabel 2 menunjukkan fungsi yang digunakan oleh pengguna untuk dapat memulai aplikasi.

Tabel 2. Pengujian menu utama

\begin{tabular}{llll}
\multicolumn{1}{c}{ No. } & \multicolumn{1}{c}{ Masukan } & \multicolumn{1}{c}{ Hasil yang diharapkan } & Hasil Penguji \\
\hline 1 & tombol Mulai & Akan masuk ke game utama & Berhasil \\
& tombol Kompetensi dasar & $\begin{array}{l}\text { Kuncul penjelasan mengenai } \\
\text { Kompetensi Dasar. }\end{array}$ & Berhasil \\
3 & tombol About & $\begin{array}{l}\text { muncul cara bermain, tujuan } \\
\text { aplikasi dan, pembuat aplikasi } \\
\text { muncul peringatan keluar dari } \\
\text { aplikasi }\end{array}$ & Berhasil \\
\hline
\end{tabular}

2. Pengujian fungsi menu KD

Pada tabel 3 menunjukkan fungsi yang digunakan oleh pengguna untuk dapat melihat Kompetensi Dasar yang dimuat di game edukasi ini.

Tabel 3. Pengujian menu KD

\begin{tabular}{cllc} 
No. & Masukan & \multicolumn{1}{c}{ Hasil yang diharapkan } & $\begin{array}{c}\text { Hasil } \\
\text { Penguji }\end{array}$ \\
\hline 1 & $\begin{array}{l}\text { Klik tombol } \\
\text { KD }\end{array}$ & $\begin{array}{l}\text { Akan muncul tampilan yang berisikan Kompetensi Dasar tentang } \\
\text { materi Ekosistem Makhluk hidup untuk kelas 5 SD }\end{array}$ & Berhasil \\
& $\begin{array}{l}\text { Klik tombol } \\
\text { kembali }\end{array}$ & Akan kembali ke main menu & Berhasil \\
\hline
\end{tabular}

3. Pengujian fungsi menu Exit

Pada tabel 4 menunjukkan fungsi yang digunakan oleh pengguna untuk keluar dari game edukasi ini.

Tabel 4. Pengujian menu exit

\begin{tabular}{cccc} 
No. & Masukan & Hasil yang diharapkan & Hasil Penguji \\
\hline 1 & Klik tombol Exit & Akan keluar dari game & Berhasil \\
\hline
\end{tabular}

4. Pengujian fungsi menu About

Pada tabel 5 menunjukkan fungsi yang digunakan oleh pengguna untuk melihat bagaimana cara bermain, tujuan aplikasi, dan pembuat aplikasi. 
Tabel 5. Pengujian menu about

\begin{tabular}{llll} 
No. & \multicolumn{1}{c}{ Masukan } & \multicolumn{1}{c}{ Hasil yang diharapkan } & Hasil Penguji \\
\hline 1 & $\begin{array}{l}\text { Klik tombol } \\
\text { About }\end{array}$ & $\begin{array}{l}\text { Menampilkan cara bermain, dan tujuan aplikasi, } \\
\text { dan }\end{array}$ & Berhasil \\
2 & Klik tombol Exit & Akan keluar dari game & Berhasil \\
\hline
\end{tabular}

5. Pengujian fungsi menu Kuis

Pada tabel 6 menjabarkan fungsi yang digunakan oleh pengguna untuk memasuki scene Kuis.

Tabel 6. Pengujian menu kuis

\begin{tabular}{|c|c|c|c|}
\hline No. & Masukan & Hasil yang diharapkan & $\begin{array}{c}\text { Hasil } \\
\text { Penguji }\end{array}$ \\
\hline 1 & Klik tombol Quiz & Memunculkan scene Quiz & Berhasil \\
\hline 2 & $\begin{array}{l}\text { Klik tombol jawaban Quiz } \\
\text { dengan nilai jawaban "benar" }\end{array}$ & $\begin{array}{l}\text { Ketika jawaban benar, maka skor akan } \\
\text { bertambah dan berganti ke soal selanjutnya }\end{array}$ & Berhasil \\
\hline 3 & $\begin{array}{l}\text { Klik tombol jawaban Quiz } \\
\text { dengan nilai jawaban "salah" }\end{array}$ & $\begin{array}{l}\text { Ketika jawaban salah, maka skor tidak } \\
\text { bertambah dan berganti ke soal selanjutnya }\end{array}$ & Berhasil \\
\hline 4 & $\begin{array}{l}\text { Skor bertambah } 10 \text { poin setiap } \\
\text { jawaban "benar" }\end{array}$ & $\begin{array}{l}\text { Skor bertambah } 10 \text { untuk setiap jawaban yang } \\
\text { benar }\end{array}$ & Berhasil \\
\hline
\end{tabular}

b. Pengujian Nonfungsional

Pengujian nonfungsional dilakukan untuk menguji apakah aplikasi ini berjalan dengan baik di berbagai perangkat, pengujian ini dilakukan dengan 3 jenis laptop yang berbeda jenis perangkat dan keberhasilan aplikasi dapat di lihat pada tabel 7 berikut :

Tabel 7. Pengujian nonfungsional

\begin{tabular}{|c|c|c|c|}
\hline No. & Masukan & Hasil yang diharapkan & $\begin{array}{c}\text { Hasil } \\
\text { Penguji }\end{array}$ \\
\hline 1 & $\begin{array}{l}\text { Lenovo G40- } \\
70\end{array}$ & $\begin{array}{l}\text { Windows } 10 \text { Pro 64bit, G40 dengan Intel(R) Core(TM) i3-4030 } \\
\text { CPU 1.90GHz (4 core), } 4 \text { GB memory dan HDD 500GB. }\end{array}$ & Berhasil \\
\hline 2 & $\begin{array}{l}\text { Acer Aspire } \\
\text { ES } 1-420\end{array}$ & $\begin{array}{l}\text { Windows } 10 \text { Enterprice } 64 \mathrm{bit} \text {, AMD A4-5100 APU Radeon HD } \\
\text { Graphics ( } 4 \text { CPUs) } \sim 1.5 \mathrm{GHz} \text {, 4GB RAM, dan HDD 500GB }\end{array}$ & Berhasil \\
\hline 2 & $\begin{array}{l}\text { Acer Aspire } \\
\text { E5-475G }\end{array}$ & $\begin{array}{l}\text { Windows } 10 \text { Pro 64it, Intel Core I5-7200 CPU @ 2.50Hz (4 } \\
\text { CPUs) } \sim 2.7 \mathrm{GHz}, 4 \mathrm{~GB} \text { RAM, dan HDD 1TB }\end{array}$ & Berhasil \\
\hline
\end{tabular}

\section{B. Pengujian Beta}

Pengujian beta dilakukan untuk mengetahui sejauh mana kualitas perangkat lunak yang sudah di bangun [8].

\section{Evaluasi Menggunakan Uj T-Berpasangan}

Pada tahap ini evaluasi dilakukan dengan teknik Penelitian Tindakan Kelas pada SDN CIbalongsari IV karawang dengan sempel siswa kelas V berjumlah 28 orang, Untuk mengetahui peningkatan pemahaman siswa terhadap game edukasi tentang materi Ekosistem Makhluk Hidup dengan melakukan uji-t berpasangan. Uji coba t-berpasangan salah satu metode pengujian hipotesis di mana data yang digunakan tidak boleh bebas yang dicirikan dengan adanya hubungan 
sampel yang sama. Uji coba ini dilakukan dengan menggunakan 2 perlakuan berbeda terhadap sampel yang sama.

Dan berikut pada tabel 8 hasil siswa sebelum dan sesudah menggunakan game edukasi sebagai media pembelajaran interaktif.

Tabel 8. Hasil pengujian pre-test dan post-test

\begin{tabular}{|c|c|c|c|c|c|}
\hline \multirow[b]{2}{*}{ No } & \multirow[b]{2}{*}{ Nama Siswa } & \multicolumn{2}{|c|}{ Hasil Evaluasi } & \multirow[b]{2}{*}{$\begin{array}{c}\text { Selisih } D=(x 1- \\
\mathrm{x} 2)\end{array}$} & \multirow[b]{2}{*}{$\mathrm{D}^{2}$} \\
\hline & & $\begin{array}{c}\text { Pre Test } \\
\text { (x2) }\end{array}$ & $\begin{array}{l}\text { Post Test } \\
\text { (x1) }\end{array}$ & & \\
\hline 1 & Reza Agustian & 80 & 80 & 0 & 0 \\
\hline 2 & Yoga Tri Pamungkas & 40 & 70 & 30 & 900 \\
\hline 3 & Malika Bimantara A & 60 & 70 & 10 & 100 \\
\hline 4 & Albiru Ayu Thohir & 60 & 90 & 30 & 900 \\
\hline 5 & Risui Rahmat K & 50 & 70 & 20 & 400 \\
\hline 6 & Risti Ayu Nadia & 70 & 70 & 0 & 0 \\
\hline 7 & Eka Khoerunniasa Z & 60 & 60 & 0 & 0 \\
\hline 8 & Salwa Fauziani & 50 & 80 & 30 & 900 \\
\hline 9 & Salfa Fauziani & 50 & 50 & 0 & 0 \\
\hline 10 & Arini Citra P & 60 & 70 & 10 & 100 \\
\hline 11 & Fadillah & 80 & 70 & -10 & 100 \\
\hline 12 & Imam Aulia Rahman & 90 & 90 & 0 & 0 \\
\hline 13 & M Ali Qran & 30 & 30 & 0 & 0 \\
\hline 14 & Syifa Alvina Maharani & 50 & 50 & 0 & 0 \\
\hline 15 & Silvia Inggrit Anggraini & 50 & 40 & -10 & 100 \\
\hline 16 & Reja Ibrahim & 70 & 60 & -10 & 100 \\
\hline 17 & Bayu Haidar & 70 & 80 & 10 & 100 \\
\hline 18 & Umer Sari & 50 & 90 & 40 & 1600 \\
\hline 19 & Makdalena & 70 & 80 & 10 & 100 \\
\hline 20 & Nuri & 60 & 80 & 20 & 400 \\
\hline 21 & Melinda & 30 & 80 & 50 & 2500 \\
\hline 22 & Shinta & 30 & 60 & 30 & 900 \\
\hline 23 & Yunita & 40 & 80 & 40 & 1600 \\
\hline 24 & Nurani & 40 & 80 & 40 & 1600 \\
\hline 25 & Aulia Rizqi Safitri & 80 & 80 & 0 & 0 \\
\hline 26 & Heni Nur'aeni & 70 & 90 & 20 & 400 \\
\hline 27 & Denissa Zalfa Aqila & 80 & 90 & 10 & 100 \\
\hline 28 & Yusuf Ardiansyah & 60 & 90 & 30 & 900 \\
\hline Jumlah & & 1630 & 2030 & 400 & 13800 \\
\hline
\end{tabular}

$\mathrm{S}=$ Standar Deviasi (Simpangan Baku) pada selisih (beda) dengan rumus pada persamaan (1):

$$
\begin{aligned}
& S=\sqrt{\frac{1}{28-1}\left\{\sum D 2-\frac{\left(\sum D\right) 2}{n}\right\}} \\
& S=\sqrt{\frac{1}{27}\left\{13800-\frac{(400) 2}{28}\right\}} \\
& S=\sqrt{\frac{1}{27}\left\{13800-\frac{80000}{28}\right\}} \\
& S=\sqrt{\frac{1}{27}\{13800-2857,1429\}} \\
& S=\sqrt{\frac{1}{27}\{10942,8571\}} \\
& S=\sqrt{405,2910} \\
& S=20,1318
\end{aligned}
$$


Sehingga diperoleh nilai $t_{\text {hitung }}$ pada persamaan (2) sebesar

$$
\text { Thitung }=\frac{\frac{\sum D}{n}}{\frac{s}{\sqrt{n}}}=\frac{\frac{400}{28}}{\frac{20,1318}{5,2915}}=\frac{14,2857}{3,8045}=3,7549
$$

Setelah itu dapat di lihat nilai $\mathrm{t}_{\text {tabel }}$ sebagai perbandingan, $\mathrm{t}_{\text {tabel }}$ dapat dilihat dengan cara pada persamaan (3):

$$
\begin{aligned}
& d f=n-1 \\
& d f=28-1=27 \\
& \begin{aligned}
t \alpha= & t 0,01(d f) \\
& =t 0,01(27) \\
& =2.47266
\end{aligned}
\end{aligned}
$$

Maka didapatkan nilai t-hitung $(3,7549)>$ t-tabel $(2.47266)$ maka Ho ditolak, dan $\mathrm{H}_{1}$ diterima. Sehingga dapat disimpulkan bahwa terdapat perbedaan hasil sebelum dan sesudah menggunakan game edukasi sebagai media pembelajaran materi Ekosistem Makhluk Hidup berhasil meningkatkan hasil belajar siswa dari segi pencapaian tujuan pembelajaran dan pemahaman materi.

\section{Uji Persentase rata-rata}

Berdasarkan hasil nilai sebelum dan sesudah menggunakan game edukasi sebagai media pembelajaran yang telah dilakukan, maka akan dihitung semua nilai hasil yang didapat dari siswa dengan presentase nilai rata-rata dengan rumus pada persamaan (4):

Presentasi nilai rata-rata

$$
=\frac{\text { Skor yang diperoleh }}{\text { Skor Maksimal }} \times 100
$$

Jumlah sebelum menggunakan game edukasi pada persamaan (5) yaitu:

$80+40+40+60+60+50+70+60+50+50+60+80+90+30+30+50+50+70+70$

$+50+70+60+30+30+40+40+80+70+80+60=1630$

Sesudah menggunakan game edukasi pada persamaan (6) yaitu:

$80+70+70+90+90+70+70+60+80+50+70+70+80+90+30+50+40+60+80+90+80$

$+80+80+60+80+80+80+90+90+90=2030$

Dan skor maksimal pada persamaan (7) yaitu:

Skor maksimal: $28 \times 100=2800$

Rata-rata sebelum pada persamaan (8) sebagai berikut:

$=\frac{1630}{2800} \times 100=58,21 \%$

Maka hasil yang di dapat pada rata-rata sebelum menggunakan game edukasi sebagai media pembelajaran yaitu sebesar $58,21 \%$, dan dapat dikatakan dalam kriteria pemahan dan keberhasilan belajar kurang layak menurut tabel tingkat kelayakan.

Rata-rata sesudah menggunakan game pada persamaan (9) yaitu :

$=\frac{2030}{2800} \times 100=72,5 \%$ 
Dan hasil yang didapat pada rata-rata sesudah menggunakan media pembelajaran sebesar $72,5 \%$, maka dapat dikatakan setelah menggunakan media pembelajaran pemahaman dan keberhasilan belajar siswa meningkat.

Sehingga dapat disimpulkan terdapat perbedaan dari hasil nilai rata-rata sebelum menggunakan media pembelajaran sebesar 58,21\% dan sesudah menggunakan media pembelajaran sebesar 72,5\% dengan selisih hasil 14,29\%.

\section{Pengujian UAT (User Acceptance Testing)}

User Acceptance Test( UAT) ataupun Uji Penerimaan Pengguna merupakan sesuatu proses pengujian oleh pengguna yang dimaksudkan buat menghasilkan dokumen yang dijadikan fakta kalau aplikasi yang sudah dikembangkan sudah bisa diterima oleh pengguna serta memeriksa apakah Visual Novel ini sudah memenuhi kriteria layak untuk digunakan [9][10]. Tingkatan penerimaan suatu sistem oleh pengguna bisa jadi suatu tolak ukur buat memperhitungkan penerimaan suatu teknologi data oleh pengguna [11].

Dalam penelitian ini mengambil sample sebanyak 28 siswa yang telah menggunakan aplikasi Game edukasi, kemudian dalam menentukan banyak sample yang di butuhkan maka digunakan rumus slovin sebagai berikut: $n=N /(1+N .(e) 2)$ dengan keterangan $: \mathrm{n}=$ jumlah sampel $\mathrm{N}=$ jumlah total populasi $\mathrm{e}=$ batas margin eror [12].

Jumlah siswa dalam riset ini sebanyak 28 orang, batasan kesalahan adalah $10 \%$. Maka didapatkan nilai $\mathrm{n}$ seperti pada persamaan (10)

$$
\begin{aligned}
& n=N /(1+N \cdot(e) 2) \\
& n=28 /(1+28 \cdot(10 \%) 2) \\
& n=28 /(1+28 \cdot(0,1) 2) \\
& n=28 /(1+28 \cdot(0,01)) \\
& n=28 /(1+0,28) \\
& n=28 / 1,28 \\
& n=21,8 \text { dibulatkan menjadi }=22
\end{aligned}
$$

\begin{tabular}{|c|c|c|c|c|c|c|c|c|c|c|c|c|}
\hline \multirow{2}{*}{ NO } & \multirow{2}{*}{ Pertanyaan } & \multicolumn{5}{|c|}{ Jawaban } & \multicolumn{5}{|c|}{ Persentase } & \multirow{2}{*}{ Bobot } \\
\hline & & $\mathbf{A}$ & B & $\mathrm{C}$ & D & $\mathbf{E}$ & A & B & C & D & $\mathbf{E}$ & \\
\hline 1 & $\begin{array}{l}\text { Apakah tampilan dari } \\
\text { aplikasi game edukasi } \\
\text { ini menarik? }\end{array}$ & 10 & 7 & 5 & 0 & 0 & $45 \%$ & $32 \%$ & $23 \%$ & 0 & 0 & 93 \\
\hline 2 & $\begin{array}{l}\text { Apakah tombol-tombol } \\
\text { dari aplikasi game } \\
\text { edukasi ini mudah } \\
\text { dipahami? }\end{array}$ & 15 & 5 & 2 & 0 & 0 & 68 & 23 & 9 & 0 & 0 & 101 \\
\hline 3 & $\begin{array}{l}\text { Apakah materi } \\
\text { pelajaran dari aplikasi } \\
\text { game edukasi ini } \\
\text { mudah dimengerti? }\end{array}$ & 7 & 4 & 10 & 1 & 0 & 32 & 18 & 45 & 5 & 0 & 83 \\
\hline 4 & $\begin{array}{l}\text { apakah aplikasi game } \\
\text { edukasi ini membantu } \\
\text { dalam proses belajar? }\end{array}$ & 17 & 5 & 0 & 0 & 0 & 77 & 23 & 0 & 0 & 0 & 105 \\
\hline
\end{tabular}

Tabel 9. Nilai Bobot

\begin{tabular}{lc}
\hline \multicolumn{1}{c}{ Jawaban } & Nilai \\
\hline $\mathrm{A}=$ Sangat Mudah & 5 \\
$\mathrm{~B}=$ Mudah & 4 \\
$\mathrm{C}=$ Netral & 3 \\
$\mathrm{D}=$ Cukup Sulit & 2 \\
$\mathrm{E}=$ Sangat Sulit & 1 \\
\hline
\end{tabular}

Tabel 10. Hasil pengujian $U A T$ 
Nilai bobot pada tabel 10 ditentukan dengan mengalikan dan menjumlahkan setiap poin jawaban dengan bobot yang sudah ditentukan pada tabel 9. Maka dapat di sumpulkan bahwa [13]:

a. Analisa pertanyaan pertama

Dari tabel di atas bisa dilihat kalau jumlah nilai dari 22 responden untuk permasalahan pertama yakni 93 . Nilai rata- ratanya ialah $93 / 22=4,2$. Prosentase nilainya adalah $4,2 /$ $5 \times 100=84 \%$.

b. Analisa pertanyaan kedua

Dari tabel di atas bisa dilihat kalau jumlah nilai dari 22 responden untuk permasalahan kedua yakni 93. Nilai rata- ratanya ialah $101 / 22=4,6$. Prosentase nilainya adalah $4,6 / 5$ $\mathrm{x} 100=92 \%$.

c. Analisa pertanyaan ketiga

Dari tabel di atas bisa dilihat kalau jumlah nilai dari 22 responden untuk permasalahan ketiga yakni 93. Nilai rata- ratanya ialah $83 / 22=3,8$. Prosentase nilainya adalah $3,8 / 5 \mathrm{x}$ $100=76 \%$.

d. Analisa pertanyaan keempat

Dari tabel di atas bisa dilihat kalau jumlah nilai dari 22 responden untuk permasalahan keempat yakni 93 . Nilai rata- ratanya ialah $105 / 22=4,8$. Prosentase nilainya adalah $4,8 /$ $5 \times 100=96 \%$.

Maka dapat di sumpulkan bahwa tampilan dari game edukasi visual novel ekosistem makhluk hidup memiliki tampilan yang menarik, tom-tombol mudah dipahami, materi mudah di mengerti dan mampu membantu proses belajar siswa.

\subsection{Distribution}

Dalam tahap ini game edukasi pembelajaran Ekosistem Makhluk Hidup yang sudah selesai dibuat dan diuji akan diberikan kepada pihak SDN Cibalongsari IV Karawang dalam format exe dalam media berupa Compact Disk (CD).

\section{KESIMPULAN}

Berdasarkan penelitian yang telah dilaksanakan maka terdapat beberapa kesimpulan dimana penelitian ini berhasil membuat game edukasi sebagai media pembelajaran yang membahas materi Ekosistem Makhluk Hidup menggunakan model pengembangan MDLC. Game edukasi ini mendapatkan nilai $100 \%$ berhasil dari pengujian fungsional dan nonfungsional. Dari hasil uji-t berpasangan menunjukan nilai t-hitung $(3,7549)>$ t-tabel (2.47266) maka Ho ditolak, dan $\mathrm{H} 1$ diterima yg menunjukan bahwa penerapan aplikasi game edukasi visual novel Ekosistem Makhluk Hidup berhasil meningkatkan hasil belajar peserta didik. Berdasarkan perbandingan tingkat efektivitas belajar siswa yang di lakukan dengan melihat nilai rata-rata pre test dan post test, didapatkan nilai pre test yang di uji sebelum menggunakan game edukasi sebesar 58,21\% dan post test yang di uji setelah menggunakan game edukasi sebesar 72,5\% dengan selisih hasil 14,29\% lebih unggul menggunakan Game edukasi. Berdasarkan Uji UAT (User Acceptance Testing) dengan pengambilan sample menggunakan metode slovin sebanyak 28 siswa dengan margin eror $10 \%$ dan mendapatkan hasil 22 sample siswa, menyatakan aplikasi game edukasi visual novel ekosistem makhluk hidup dapat diterima oleh siswa dengan analisis tampilan yang menarik sebanyak $85 \%$, fungsi tombol $92 \%$, pemahaman materi $76 \%$, dan membantu proses belajar $96 \%$. 


\section{DAFTAR PUSTAKA}

[1] A. V. Vitianingsih, "Game Edukasi Sebagai Media Pembelajaran Pendidikan Anak Usia Dini," Inform, vol. 1, no. 1, pp. 1-8, 2016.

[2] M. R. Kusuma, H. Djamil, I. Bastian, and A. Rosadi, "Pembuatan Visual Novel dengan Tujuan Edukasi Berbasis Android," vol. 1, no. 1, 2017.

[3] Fakhriyanur, Pengembangan Media Pembelajaran Interaktif teknik Animasi 2 Dimensi Berbasis Adobe Flash Untuk Siswa kelas XI Multimedia Di SMK Muhammadiyah 1 Yogyakarta, vol. 05, no. 02. 2016.

[4] H. Sugiarto, "Penerapan Multimedia Development Life Cycle Pada Aplikasi Pengenalan Abjad Dan Angka," IJCIT (Indonesian J. Comput. Inf. Technol., vol. Vol.3 No.1, no. 1, pp. 26-31, 2018.

[5] N. U. Ainon Mardhiah, Yusrizal, "Peningkatan Profesionalitas Guru Melalui," J. Adm. Pendidik. Realita Vol. 15, No. 2 Tahun 2017, vol. 4, no. 2, pp. 1-11, 2017, doi: 10.1016/j.det.2012.08.002.

[6] Taufik, "Game Edukasi Visual Novel Pembelajaran Sistem Peredaran Darah Pada Manusia Untuk Kelas 5 SD / MI ( Studi Kasus : Sds K Maranatha Karawang )," Singaperbangsa Karawang, Karawang, 2019.

[7] Joni Suhartono, "Alpha Testing," Binus University School of Information Systems, 2016. https://sis.binus.ac.id/2016/12/16/alpha-testing/ (accessed Jan. 15, 2020).

[8] Joni Suhartono, "Beta Test," Binus University School of Information Systems, 2016. https://sis.binus.ac.id/2016/12/16/beta-test/ (accessed Jan. 15, 2020).

[9] I. A. Prasetya and N. Safriadi, "Penerapan Visual Novel Dari Cerita Rakyat Asal Usul Kota Pontianak," vol. 1, no. 1, pp. 1-5, 2015.

[10] M. A. Nurdin and I. Hermawan, "Analisis Dan Pengembangan Aplikasi Inhouse Klinik Perusahaan Menggunakan Framework Codeigniter, Studi Kasus Pt Reckitt Benckiser Indonesia," vol. 3, no. 1, 2017, [Online]. Available: http://www.jurnal.stmikmi.ac.id/index.php/jcb/article/view/208/231.

[11] A. J. Nathan and A. Scobell, "Implementasi Dan User Acceptance Test (Uat) Terhadap Aplikasi E-Learning Pada Madrasah Aliyah Negeri (Man) 3 Kota Banda Aceh," Foreign Aff., vol. 91, no. 5, pp. 1689-1699, 2012, doi: 10.1017/CBO9781107415324.004.

[12] D. Darmawan, "Pengaruh Kualitas Layanan, Biaya Pendidikan Dan Fasilitas Pendidikan Terhadap Keputusan Konsumen Dengan Brand Image Sebagai Variabel Intervening Dalam Memilih Program Studi Pada Fakultas Ekonomi Universitas Kristen Artha Wacana Kupang," J. Chem. Inf. Model., vol. 53, no. 9, pp. 1689-1699, 2019, doi: 10.1017/CBO9781107415324.004.

[13] Iqbal Abdullah Sulthan, "Pengertian User Acceptance Testing (UAT)," www.scribd.com, 2017. https://www.scribd.com/document/353215577/Pengertian-User-AcceptanceTesting-UAT. 